It is not possible to impart to an engineer such a knowledge of geology as will enable him to appreciate or deal with various geological problems that he may be confronted with in practice. He should, however, know enough to recognize when he is faced with a problem in which geological advice is essential.

Two thirds of this text-book is an elementary course of geology including petrology and mineralogy but excluding palæontology. It is presented in too condensed a form to serve as a cultural study and, on the other hand, is too abstruse to be of direct service to an engineer. It is difficult to see the usefulness to such a student of a knowledge of minerals like antigorite, axinite, celsian, dickite, to choose a few at random, or such rocks as brucite marble, wollastonite marble, teschenite or the deep sea red clay, or again such structures as the ring dykes and cone sheets of the wast of Scotland. All such matter and much besides could well have been severely pruned in the interest of the engineer.

On the other hand, the section on the use and interpretation of geological maps could well have been expanded, though the best manner of imparting this knowledge is in practical classes, where actual geological maps on various scales are handled rather than the outline maps habitually used in the instruction of geological students.

Only the latter third of this book is devoted to certain aspects of geology as applied to engineering. These include the geology of water supply, of reservoirs and dam sites, and of cuttings and tunnels, which are well presented though they might with advantage be somewhat fuller.

It is noteworthy that only a minute fraction of the information contained in the first two hundred pages of the book is necessary in order to understand the section devoted to engineering problems.

Of late years, engineers have begun to be interested in a branch of civil engineering called soil mechanics, and in the applications of geophysical methods to engineering problems. Mr. A. W. Skempton, who is an acknowledged authority on soil mechanics, has contributed an appendix on this subject which is one of the most useful parts of the book. An appendix on geophysics is supplied by Dr. Bruckshaw, while a third appendix is devoted to a useful list of the publications of the Geological Survey of Great Britain.

O. T. Jones.

\section{BRITISH TIMBERS}

\section{British Timbers}

Their Properties, Uses and Identification; with Notes on the Growth and Cultivation of the Trees. By E. H. B. Boulton and B. Alwyn Jay. Pp. 112+31 plates. (London: Adam and Charles Black, Ltd., 1944.) 12s. 6d. net.

7 HIS book, with ninety-four pages of text, sixty drawings of transverse and tangential sections, and thirty-one plates showing the plain, quartered and transverse sections of British woods, should prove useful to architects, engineers, builders, and others who are employed or interested in the uses of timber. The little volume embraces all phases-from the seed to the mature tree and the timber.

The planting of trees in England, which in earlier years attracted the interest of a wide section of the people, insensibly diminished year by year until, as the authors say : "The extremely important part played by home-grown timbers in the world war has resulted in a revival of interest in our own woods, and an accompanying demand for information about them". The period between the War of 1914-18 and the present War witnessed an improvement in the public attitude, but not nearly of sufficient consequence to meet the terrible demands of the years 1939-44.

The qualities of British grown timber, and its uses, have been neglected for more than a hundred years. This book comes at a propitious moment, meeting a long-existing need.

The general unfortunate impression has prevailed that Great Britain cannot produce timber of useful quality to compete with foreign supplies. We now know this view to be wrong. The outcome of the debate in Parliament, and the report of the Forestry Commission, if they served no other purpose, at least emphasized the fact that as good and better timber can be grown in Great Britain as in any other country of similar climate. Moreover, many illustrations have emerged; for example, the quality of Scots pine (Pinus sylvestris) from one estate yielded prime clear boards free of knots, and of a texture equal to the best that has been seen from Finland, and approximating to the quality of Archangel. Douglas fir (Pseudotsuga Douglasii-P. taxifolia) can claim similar success in competition with that from British Columbia. Before this War there were few who would have thought it possible for aerial poles to be provided of a height of $95 \mathrm{ft}$., with a diameter of 9 in. at the top, and from trees not exceeding eighty years old, if as much, but this has been accomplished. Redwood (Sequoia sempervirens), of intrinsic quality, as good as that from California, has been grown; but the want of scientific practice of forestry has resulted in the tree producing too many branches, which means too many knots. In England the general lack of information, and the entire absence of this scientific practice for so many years, was partially responsible for the reluctance of the wood. working industry to employ home-grown timber. Perhaps a more serious feature has been the exceed ingly high cost of transport, especially railway rates, which have operated differentially, to the disadvantage of home-grown timber. The authors deal with some of these questions, and afford an opportunity for the study and acceptance of an entirely new outlook.

The book contains eight chapters. Chapter 1, "British trees and their Cultivation", is a good outline in principle, giving a working basis for the amateur planter, with information as to type of soil, planting, etc. Chapter 2, on "The Properties of Wood", deals lightly with many aspects, including grain, moisture content, attack by fungi and beetles, durability, seasoning by air and kiln driers, etc. The chapter on the "Identification of Timbers commonly grown in Britain" contains some good diagrams, and should prove useful in identification, perhaps requiring the assistance and confirmation of the photomicrograph. The chapters dealing with "Hardwoods and Softwoods" are comprehensive and well condensed, giving useful and interesting information. While the plates are interesting, it is doubtful, having regard to the cost of production, whether they provide sufficient interest to warrant their inclusion.

Never before in the history of Great Britain have our woodlands been so fearfully devastated, and the first necessity with which we are confronted is their restoration. At the same time, we should learn from the experience of the last few years to adapt our methods so that our home-grown timbers may be employed to the best advantage. 